\title{
Dietary fibre, lente carbohydrates and the insulin-resistant diseases
}

\author{
David J. A. Jenkins ${ }^{1}{ }^{*}$, Mette Axelsen ${ }^{2}$, Cyril W. C. Kendall ${ }^{1}$, Livia S. A. Augustin ${ }^{1}$, Vladimir Vuksan ${ }^{1}$ \\ and Ulf Smith ${ }^{2}$ \\ ${ }^{1}$ Department of Nutritional Sciences, Faculty of Medicine, \\ University of Toronto and the Clinical Nutrition and Risk Factor Modification Center, St Michael's Hospital, \\ Toronto, Ontario, Canada \\ ${ }^{2}$ Lundberg Laboratory for Diabetes Research, Department of Internal Medicine, Sahlgrenska University Hospital, \\ Göteborg, Sweden
}

\begin{abstract}
Several epidemiological studies link consumption of fibre-rich foods to a reduced risk of type 2 diabetes and CHD. The 'fibre hypothesis' suggested that this was a direct effect of fibre. However, fibre-rich foods contain different types of fibre as well as other potentially beneficial compounds, and many foods naturally high in fibre have low glycaemic and insulinaemic indices, possibly due to food form. The question therefore emerges as to the effect of isolated fibre per se on insulin sensitivity, lipids and other risk factors associated with the metabolic syndrome. Many beneficial effects are seen with pharmacological doses of isolated viscous soluble fibre, including improved insulin sensitivity, decreased LDL-cholesterol levels and decreased clotting factors. Similar effects are seen with low glycaemic-index foods. In contrast, insoluble non-viscous cereal fibre is not seen to act directly on risk factors when taken in refined foods such as in milled flour. Since cereal fibre, the major type of fibre in western diets, does not directly act on the risk factors for the metabolic syndrome, the question remains as to possible mechanisms. Until now, fibre and the nature and processing of the starch and particle size have been seen as the main determinants of the metabolic response to starchy foods. However, fibre-rich foods also have an increased protein-to-carbohydrate ratio. Hence we suggest that the protective effect of fibre may also be due to increased vegetable protein content, which may act directly to reduce clotting factors and oxidized LDL-cholesterol levels.
\end{abstract}

Insulin resistance: Dietary fibre: Low glycaemic index: Diabetes mellitus type 2: Cardiovascular diseases

\section{Introduction}

Affluent western lifestyles are associated with a number of chronic diseases including diabetes, CHD and cancer. Links have been established between sloth (Dorn et al. 1999; Manson et al. 1999) and gluttony (Higgins et al. 1993; Hu et al. 1997) and a number of chronic diseases. On the other hand the dietary fibre hypothesis proposed that these same diseases were the result of a lack of fibre in the diet (Burkitt et al. 1972; Trowell 1978). Several observational studies have provided strong support for a beneficial role of what is termed whole-grain intake in reducing the risk of CHD (Jacobs Jr et al. 1998; Liu et al. 1999). In addition, high intakes of whole-grain foods have been suggested to reduce the risk of developing diabetes (Salmeron et al. 1997a, b), hypertension, and some types of cancer (Levi et al. 1999). Since diabetes, cardiovascular disease and probably cancer are associated with insulin resistance, there is considerable interest in whether fibre might reduce insulin resistance.

\section{Hypothesis: fibre and insulin resistance}

The working hypothesis is that fibre-depleted foods will lead to higher glucose levels and stimulate excessive insulin secretion. Hyperinsulinaemia, in turn, may result in downregulation of the insulin receptors, lower levels of relevant signalling molecules (Virkamäki et al. 1999), and thus an elevation of the fasting blood glucose. Once insulin resistance is established there may be an even greater sensitivity to the deleterious effect of low-fibre, high glycaemic-index foods, thus maintaining a vicious cycle (Fig. 1). Viscous fibre may act to break this cycle by reducing the rate of absorption and lowering the postprandial glycaemic and insulinaemic responses. To achieve these effects, viscous

*Corresponding author: D. J. A. Jenkins, fax +1 416978 5310, email cyril.kendall@utoronto.ca 
Low fibre - high glycaemic-index foods

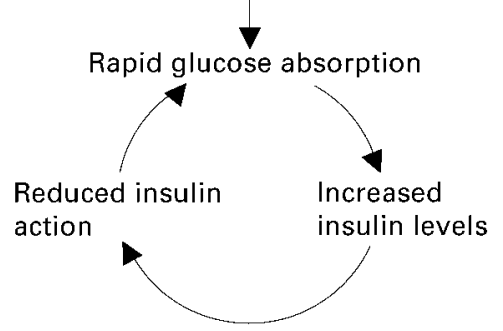

Fig. 1. Potential mechanisms for the relationship between dietary fibre and insulin resistance.

fibres convert the small intestine into a storage organ for the slow release of glucose to the portal circulation. In this way fibre may impact on western chronic diseases. Alternatively, fibre and low glycaemic foods may operate by mechanisms separate from insulin resistance by acting directly on risk factors for chronic disease.

\section{Lente carbohydrate}

A number of mechanisms may operate to reduce the rate of carbohydrate absorption. Enzyme access to starch may be retarded. Viscous fibre may impede bulk diffusion of the products of luminal digestion to the mucosal surface. Other factors, possibly more important in everyday life, are taking foods resistant to rapid digestion (low glycaemic-index foods) (Jenkins et al. 1981), taking more frequent, smaller meals (nibbling) (Jenkins et al. 1989; Powell et al. 1999), or directly inhibiting amylolytic digestion and disaccharide absorption ( $\alpha$-glucosidase inhibitors). The glycaemic index of the food, in turn, is dependent on the nature (Granfeldt et al. 1995; Liljeberg et al. 1996) and processing (Ross et al. 1987; Collings et al. 1981; Granfeldt et al. 1994) of the starch; food particle size such as whole grains (Jenkins et al. 1988; Liljeberg et al. 1992; Järvi et al. 1995); the presence of viscous fibres (Torsdottir et al. 1989), and the interaction of other nutrients with the starch. The factors resulting in the production of lente carbohydrate foods are thus interconnected, and in many studies it is not easy to separate the different effects of viscous fibre and low glycaemic-index foods. Their effects will therefore be addressed together and separated from the effects of insoluble fibre on insulin resistance and other risk factors for chronic disease.

\section{Viscous fibre, lente carbohydrate and insoluble fibre}

Whole-grain foods often have a low glycaemic index and also provide dietary fibre, resistant starch, minerals, vitamins, phytochemicals, vegetable protein and other substances. The specific role of the fibre in modifying insulin sensitivity and risk factors for CHD has challenged investigators and clinicians for around two decades. Some studies in diabetic subjects have reported improved insulin sensitivity or decreased insulin needs by the use of foods rich in cereal fibre (Karlström et al. 1984; Harold et al. 1985). However, isolated cereal fibre does not appear to reduce the rate of carbohydrate absorption when the integrity of the whole grain is destroyed, as in the making of flour. Only in one study did chronic bran feeding improve postprandial glucose and insulin levels in persons with impaired glucose tolerance (Bosello et al. 1980). Hence the role of cereal fibre per se in the metabolic syndrome remains unclear.

In contrast, isolated soluble fibre is seen to decrease serum total cholesterol and LDL-cholesterol concentrations (Jenkins et al. 1979; Bosello et al. 1984). Moreover, when the viscous fibre guar was given as a supplement to 25 healthy men, $10 \mathrm{~g}$ three times a day for 6 weeks, insulin sensitivity, triglyceride levels, clotting factors and blood pressure were improved (Landin et al. 1992). Similar results have been seen in type 2 diabetics receiving $4 \mathrm{~g}$ of guar twice a day (Tagliaferro et al. 1985). In another study of healthy men, a high-carbohydrate, high-fibre (soluble and insoluble fibre) diet also improved insulin sensitivity and cholesterol levels (Fukagawa et al. 1990). In contrast, the addition of $15 \mathrm{~g}$ guar gum to a standard diet was of no benefit to type 1 diabetic patients either in metabolic control or insulin sensitivity; only cholesterol levels were decreased (Bruttomesso et al. 1991). A recent meta-analysis of studies using isolated fibre sources (pectin or guar gum) or fibreenriched ingredients (oat bran or psyllium) confirmed that viscous fibres significantly reduce LDL-cholesterol levels whereas no effect of soluble fibre is seen on HDL-cholesterol or triglycerides (Brown et al. 1999). Thus, despite the effect of viscous fibre in decreasing the rate of glucose absorption when taken in pharmacological doses, its use in the prevention of the metabolic syndrome needs further clarification.

When intact foods are considered as the source of fibre, reductions are seen in LDL and the apolipoprotein B : A1 ratio in hyperlipidaemic subjects (Jenkins et al. 1993), and the overall effect on insulin sensitivity and risk factors for CHD appears to be greater. Similar effects are seen with low glycaemic-index foods. Insulin sensitivity measured using the short insulin-tolerance test was greatly improved following a 3-week low glycaemic-index diet in healthy women with or without a family history of CHD (Frost et al. 1998). A recent study by Järvi et al. (1999) using a low compared to high glycaemic-index diet in 20 type 2 diabetics failed to find improved insulin sensitivity, but demonstrated reduced mean day-long blood glucose and insulin levels, and reduced serum fructosamine and plasminogen activator inhibitor-1. Previous studies have demonstrated beneficial effects with low glycaemic-index diet on glycaemic control, but none has noted effects on clotting factors. The finding of low plasminogen activator inhibitor-1 with lente carbohydrate foods is therefore of potential interest for CHD risk reduction.

Increased body weight contributes to insulin resistance and risk of diabetes and CHD. In this respect the study by Ludwig et al. (1999) is of particular importance in demonstrating that food form and glycaemic load (glycaemic index $\times$ total carbohydrate) of the preceding meal predicts food intake of a subsequent meal in obese boys (Fig. 2). Such studies raise questions concerning the role of nutrient release on glycaemic and endocrine responses as triggers of appetite, and the degree to which they can be modified by fibre and glycaemic-index changes.

Although the studies demonstrating differences in insulin sensitivity are few, a growing number of studies demonstrate 


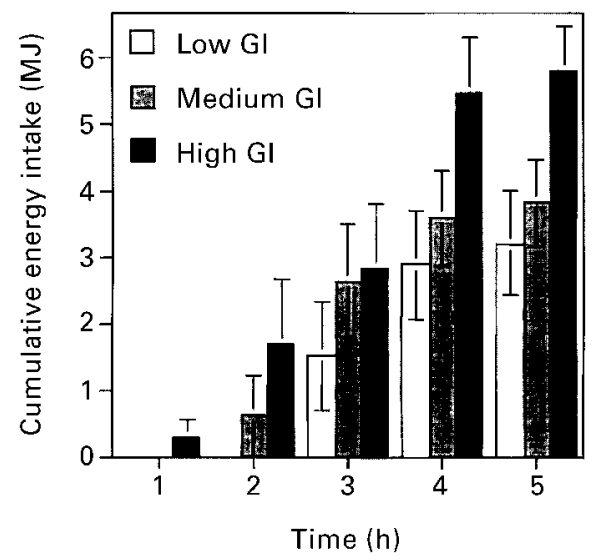

Fig. 2. Cumulative ad libitum food intake $1-5 \mathrm{~h}$ after lunch in obese boys fed breakfasts and lunches with different glycaemic index (Gl). Source: Ludwig et al. 1999; published with the consent of the author.

beneficial effects of viscous soluble fibre-low glycaemicindex diets on risk factors associated with the insulin resistance-associated diseases. There are also studies demonstrating improved serum lipids, carbohydrate tolerance and glycaemic control with insoluble (wheat) fibre (Bosello et al. 1980), but the majority of studies have failed to find significant effects in acute and short-term studies. A picture therefore emerges indicating a broad range of risk-reduction benefits for viscous fibre-low-GI diets without demonstrated changes in insulin sensitivity (Table 1). On the other hand, insoluble cereal fibre in whole-grain foods
Table 1. Fibre and low glycaemic-index (GI) effects

\begin{tabular}{lccc}
\hline Study & $\begin{array}{c}\text { Low-Gl } \\
\text { foods }\end{array}$ & $\begin{array}{c}\text { Soluble } \\
\text { fibre }\end{array}$ & $\begin{array}{c}\text { Insoluble } \\
\text { fibre }\end{array}$ \\
\hline Controlled studies & & & \\
$\quad$ Reduced glycaemic response & + & + & - \\
$\quad \begin{array}{l}\text { Reduced serum lipids } \\
\text { Reduced clotting factors }\end{array}$ & + & + & - \\
Epidemiological studies & + & + & $?$ \\
$\quad$ Reduced risk of diabetes & + & $?$ & \\
Reduced risk of CHD & + & $?$ & + \\
\hline
\end{tabular}

may be associated with increased insulin sensitivity in the context of high-fibre, high-carbohydrate diets, but with less clear acute benefits on glucose and lipid metabolism when insoluble fibre is taken without dietary change.

\section{Epidemiological studies}

Viscous soluble fibre consumption has not been shown to have benefits in epidemiological studies, probably because it is not separated from non-viscous soluble fibres in the majority of data, and because, in general, intake levels are low in western populations where the epidemiological studies are carried out (Table 1).

In contrast, slow-release carbohydrate foods in low glycaemic-index diets have been shown to reduce the risk of diabetes (Salmeron et al. 1997a, b) (Figs. 3 and 4). This may relate to a decreased insulin demand by consumption of minimally refined forms of grains. Similar effects have been

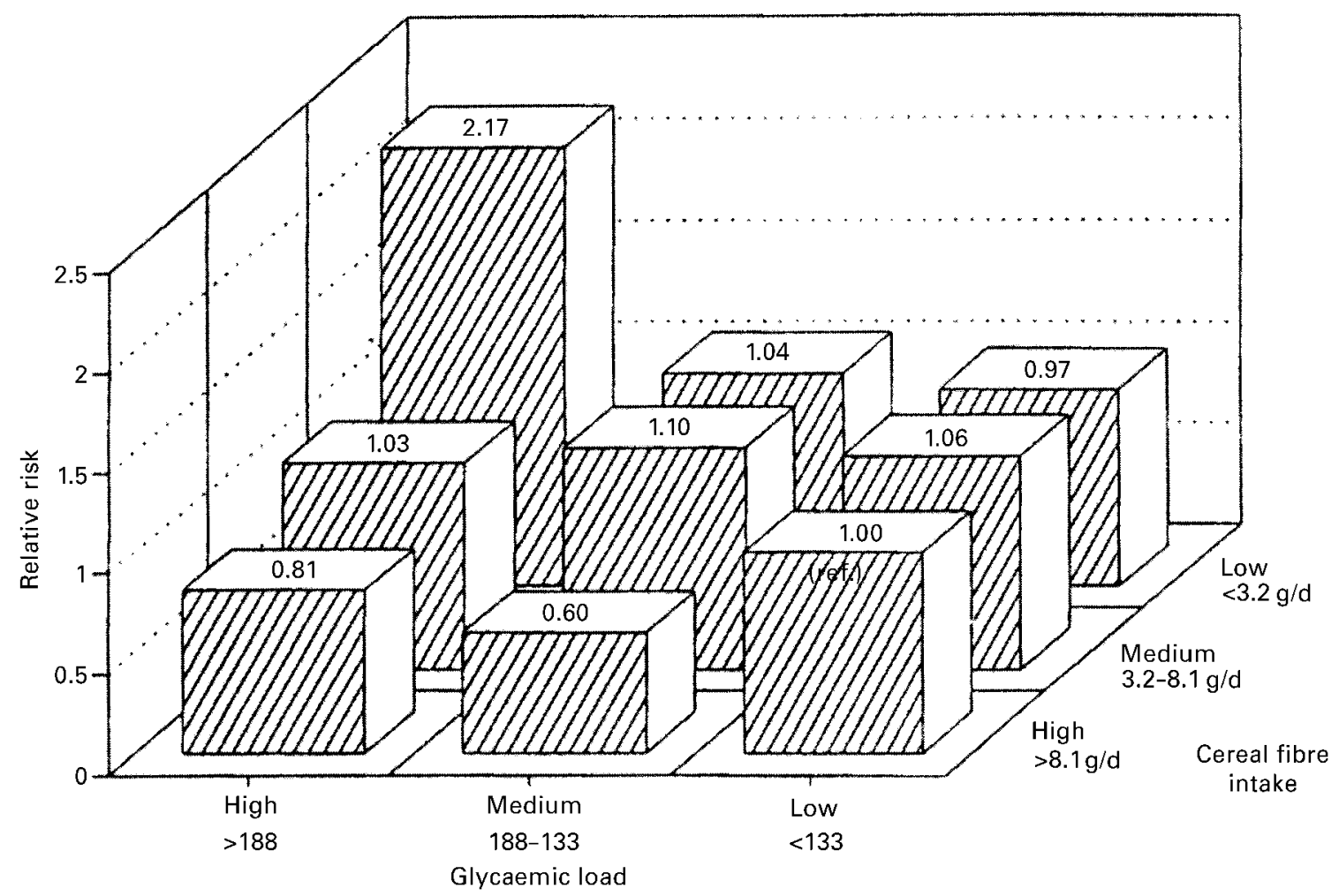

Fig. 3. Relative risk of non-insulin-dependent diabetes mellitus by different levels of cereal fibre intake and glycaemic load in women. Source: Salmeron et al. 1997b; published with the consent of the author. 


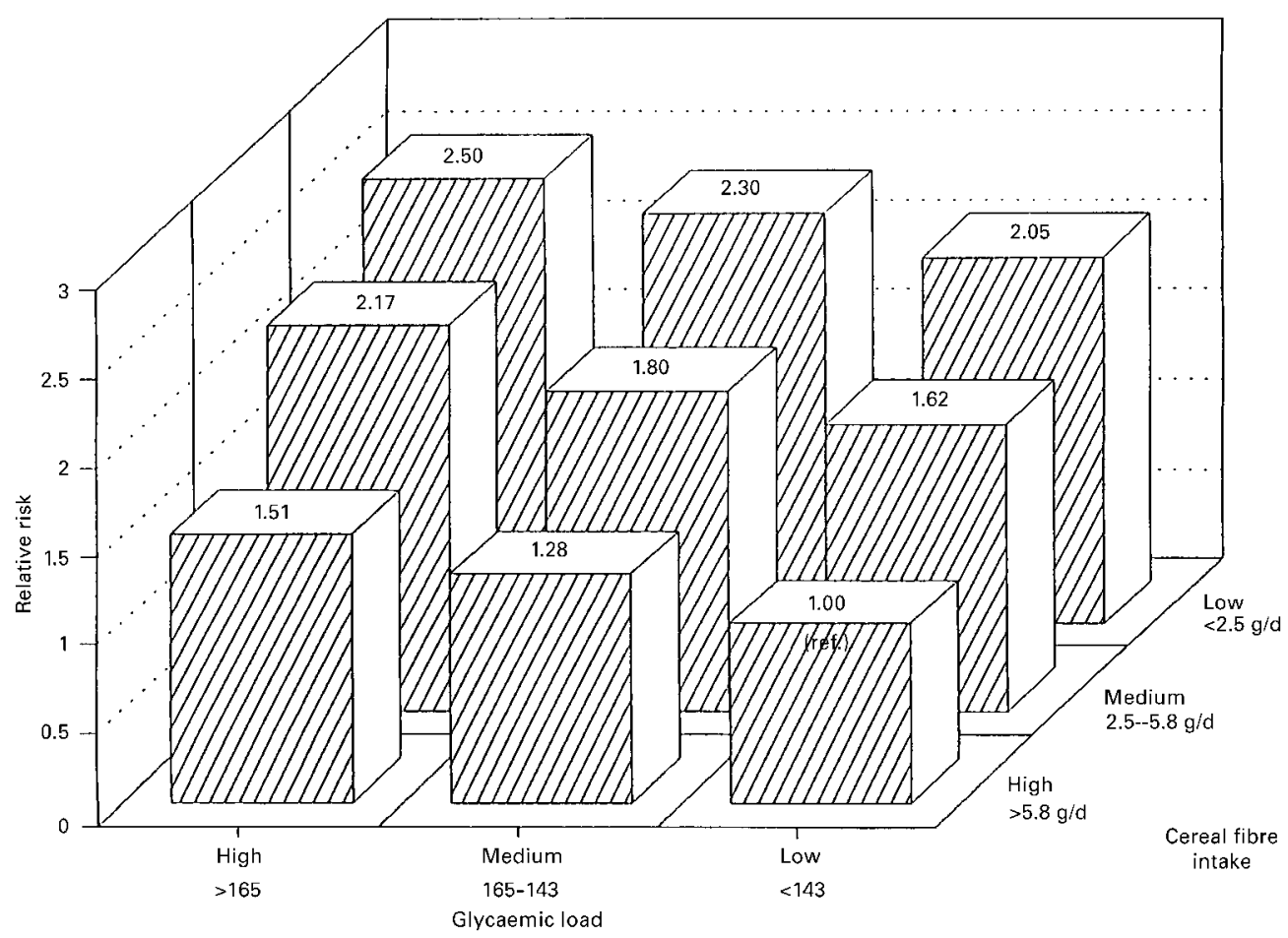

Fig. 4. Relative risk of non-insulin-dependent diabetes mellitus by different levels of cereal fibre intake and glycaemic load in men. Source: Salmeron et al. 1997a; published with the consent of the author.

seen with low glycaemic-index foods in relation to heart disease in the Nurses' Study (Liu et al. 1999). The greatest effect on CHD risk reduction with low glycaemic-index intake is seen at the highest BMI and, thus in the presumably more insulin-resistant individuals, further suggesting an interaction between glycaemic index and insulin resistance (Liu et al. 1998). The higher HDL levels may be the lipid changes that are responsible in part for the reduced risk of heart disease associated with low glycaemic-index diets (Luscombe et al. 1999). It is also possible that higher HDL levels may be a reflection of reduced insulin resistance. Both a survey of British adults $(n=2200)$ (Frost et al. 1999) and NHANES III data $(n=\mathrm{n}=30908)$ (Ford \& Liu 1999; Fig. 5) indicate that higher HDL levels are seen

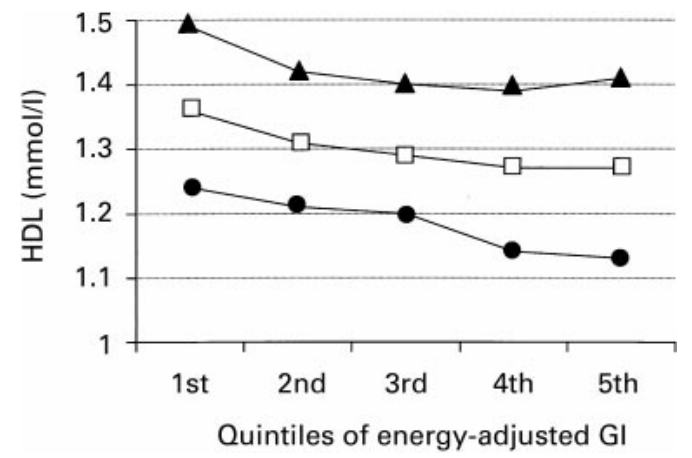

Fig. 5. Mean concentration of HDL according to quintiles of energyadjusted glycaemic index (Gl): squares, adults aged 20+; triangles, women; circles, men. The Third National Health and Nutrition Examination Survey (NHANES III) (30 908 subjects), $P<0.00001$. Source: Ford \& Liu, 1999; published with the consent of the author. associated with low glycaemic-index diets. Another reason may relate to clotting factor improvements.

Perhaps more surprising is the linked association of insoluble fibre with diabetes and CHD risk in cohorts studied (Table 1). Since 1979 studies have repeatedly shown that fibre, and cereal fibre in particular, results in a reduced risk of CHD (Rimm et al. 1994). It has been estimated that an additional $5 \mathrm{~g}$ of cereal fibre per day will reduce the risk of CHD by $37 \%$ (Wolk et al. 1999). Recent data from the Nurses' Study also suggest that increased intake of whole grains may protect against CHD (Liu et al. 1999). Interestingly, the lower risk associated with higher whole-grain intake was not fully explained by its contribution to intakes of dietary fibre, indicating that other component(s) of whole grains, separate from fibre, may also act to reduce the risk of CHD. Moreover, both the Nurses' Study (Salmeron et al. 1997b) and the Health Professionals Study (Salmeron et al. 1997a) showed an independent and inverse relation between cereal fibre and risk of type 2 diabetes (Figs 3 and 4).

\section{Cereal fibre and increased vegetable protein intake}

In the absence of an effect of cereal fibre on glycaemic control, serum lipids, or other risk factors for diabetes or $\mathrm{CHD}$, the question remains as to the possible mechanism. When wheat fibre is given as wheat bran in experimental studies, it becomes important to balance the protein intake on the control phase with additional fibre-free sources of protein (Table 2). In epidemiological studies this results in a higher protein:starch ratio on a high wheat-fibre diet compared to a low-fibre diet, due to the higher ratio in 
Table 2. Protein in wholemeal/whole-grain foods and bran

\begin{tabular}{lccccc}
\hline & \multicolumn{5}{c}{ Contents per 100 } \\
\cline { 2 - 6 } Food & $\begin{array}{c}\text { Calories } \\
(\mathrm{kcal})\end{array}$ & $\begin{array}{c}\text { Fat } \\
(\mathrm{g})\end{array}$ & $\begin{array}{c}\text { Protein } \\
(\mathrm{g})\end{array}$ & $\begin{array}{c}\text { CHO } \\
(\mathrm{g})\end{array}$ & $\begin{array}{c}\text { Protein/CHO } \\
(\%)\end{array}$ \\
\hline Breads & & & & & \\
$\quad$ White bread & 235 & 1.9 & 8.4 & 49.3 & 17 \\
$\quad$ Wholemeal bread & 215 & 2.5 & 9.2 & 41.6 & 22 \\
$\quad \begin{array}{l}\text { Cereals } \\
\quad \text { Cornflakes }\end{array}$ & 360 & 0.7 & 7.9 & 85.9 & 9 \\
$\quad$ Allbran & 261 & 3.4 & 14.0 & 46.6 & 30 \\
$\begin{array}{l}\text { Bran } \\
\quad \text { Wheat bran }\end{array}$ & 206 & 5.5 & 14.1 & 26.8 & 53 \\
\hline
\end{tabular}

Source: McCance \& Widdowson, 1991. CHO, carbohydrate.

Table 3. Effects of breakfast of starch-free (SF) bread (high in soy protein and monounsaturated fatty acids) in eight type 2 diabetic patients

\begin{tabular}{llccc}
\hline Parameter & Bread & Before & After & $P$ \\
\hline F-blood glucose & Ordinary & $11.6 \pm 3.1$ & $11.8 \pm 2.5$ & NS \\
& SF & $13.3 \pm 3.5$ & $10.2 \pm 2.0$ & $<0.006$ \\
HbA1c (\%) & Ordinary & $8.6 \pm 1.4$ & $8.4 \pm 1.4$ & NS \\
& SF & $9.0 \pm 1.4$ & $8.1 \pm 1.5$ & $<0.02$ \\
S-cholesterol & Ordinary & $5.7 \pm 0.8$ & $5.8 \pm 0.7$ & NS \\
& SF & $5.8 \pm 0.6$ & $5.5 \pm 0.5$ & $=0.05$ \\
\hline
\end{tabular}

Source: Stilling et al. 1999: data published with the consent of the author.

wheat bran. This effect is even reflected, although to a much more limited extent, in wholemeal or whole-grain breads (Table 2). The same is true for breakfast cereals and other foods where wheat bran or wholemeal flour is used in place of white flour. It is therefore possible in studies where either white or bran cereal products are eaten that the effects observed may in part be related to protein, although other components of whole grains including specific protein fractions or other fibre-associated compounds may also be responsible.

Protein breads have been shown to improve carbohydrate tolerance, and over 3-month periods to reduce HbA1c in type 2 diabetic subjects (Stilling et al. 1999; Table 3). In hyperlipidaemic subjects gluten (wheat protein) reduces serum triglyceride levels (Jenkins et al. 1999), and in the Nurses' Study increased protein intake was associated with reduced risk of ischaemic heart disease (Hu et al. 1999). Soy proteins have attracted recent attention for their ability to reduce serum lipids and act as antioxidants (Lichtenstein 1998) possibly related to their flavonoid content, and consumption of soy in China and Japan has been proposed as one reason for the longevity and freedom from many western diseases.

\section{Conclusions}

There is limited evidence to suggest that fibre (soluble or insoluble) or low-GI foods reduce insulin resistance. However, in reviewing the literature, whole-grain foods and low glycaemic-index foods are emerging as dietary constituents that appear to reduce the likelihood of disease complications by reducing risk factors for the insulin-resistant diseases.
Although a reason for the effects of viscous fibre and low glycaemic-index foods is evidently based on slowing the rate of absorption and creating a late reservoir in the small intestine, the mechanism of action of insoluble (cereal) fibre remains obscure. It is suggested that, despite its lack of effect in acute studies, the protein content of wheat bran may in part be responsible for some of the beneficial effects seen in cohort studies. Beneficial effects may also be attributable to other components of the whole grain. It is therefore justified to focus on the interaction of vegetable protein with starchy foods, in addition to the effect of fibre, the nature of the starch, degree of gelatinization and particle size.

\section{References}

Bosello O, Ostuzzi R, Armellini F, Micciolo R \& Scuro LA (1980) Glucose tolerance and blood lipids in bran-fed patients with impaired glucose tolerance. Diabetes Care 3, 46-49.

Bosello O, Cominacini L, Zocca I, Garbin U, Ferrari F \& Davoli A (1984) Effects of guar gum on plasma lipoproteins and apolipoproteins C-II and C-III in patients affected by familial combined hyperlipoproteinemia. American Journal of Clinical Nutrition 40, 1165-1174.

Brown L, Rosner B, Willett W \& Sacks F (1999) Cholesterollowering effects of dietary fiber: a meta-analysis. American Journal of Clinical Nutrition 69, 30-42.

Bruttomesso D, Biolo G, Inchiostro S, Fongher C, Briani G, Duner E, Marescotti M, Iori E, Tiengo A \& Tessari P (1991) No effects of high-fiber diets on metabolic control and insulin-sensitivity in type 1 diabetic subjects. Diabetes Research and Clinical Practice 13, 15-21.

Burkitt DP, Walker AR \& Painte, NS (1972) Effect of dietary fibre 
on stools and the transit-times, and its role in the causation of disease. Lancet 2, 1408-1412.

Collings P, Williams C \& Macdonald I (1981) Effects of cooking on serum glucose and insulin responses to starch. British Medical Journal 282, 1032.

Dorn JP, Cerny FJ, Epstein LH, Naughton J, Vena JE, Winkelstein WJ, Schisterman E \& Trevisan M (1999) Work and leisure time physical activity and mortality in men and women from a general population sample. Annals of Epidemiology 9, 366-373.

Ford E \& Liu S (1999) Glycemic index, glycemic load, and serum high-density lipoprotein (HDL) cholesterol concentration among United States adults. Circulation, in press (abstr.).

Frost G, Leeds A, Trew G, Margara R \& Dornhorst A (1998) Insulin sensitivity in women at risk of coronary heart disease and the effect of a low glycemic diet. Metabolism 47, 1245-1251.

Frost G, Leeds A, Doré C, Madeiros S, Brading S \& Dornhorst A (1999) Glycaemic index as a determinant of serum HDLcholesterol concentration. Lancet 353, 1045-1048.

Fukagawa N, Anderson J, Hageman G, Young V \& Minaker K (1990) High-carbohydrate, high-fiber diets increase peripheral insulin sensitivity in healthy young and old adults. American Journal of Clinical Nutrition 52, 524-528.

Granfeldt Y, Liljeberg H, Drews A, Newman R \& Björck I (1994) Glucose and insulin responses to barley products: influence of food structure and amylose-amylopectin ratio. American Journal of Clinical Nutrition 59, 1075-1082.

Granfeldt Y, Drews A \& Björck I (1995) Arepas made from high amylose corn flour produce favorably low glucose and insulin responses in healthy humans. Journal of Nutrition 125, 459465.

Harold M, Reeves R, Bolze M, Guthrie R \& Guthrie D (1985) Effect of dietary fiber in insulin-dependent diabetics: insulin requirements and serum lipids. Journal of the American Dietetic Association 85, 1455-1461.

Higgins M, D'Agostino R, Kannel W, Cobb J \& Pinsky J (1993) Benefits and adverse effects of weight loss. Observations from the Framingham Study. Annals of Internal Medicine 119, 758763.

Hu FB, Stampfer MJ, Manson JE, Rimm E, Colditz GA, Rosner BA, Hennekens CH \& Willett WC (1997) Dietary fat intake and the risk of coronary heart disease in women. New England Journal of Medicine 337, 1491-1499.

Hu F, Stampfer M, Manson J, Rimm E, Colditz G, Speizer F, Hennekens C \& Willett W (1999) Dietary protein and risk of ischemic heart disease in women. American Journal of Clinical Nutrition 70, 221-227.

Jacobs Jr DR, Meyer KA, Kushi LH \& Folsom AR (1998) Wholegrain intake may reduce the risk of ischemic heart disease death in postmenopausal women: the Iowa Women's Health Study. American Journal of Clinical Nutrition 68, 248-257.

Järvi A, Karlström B, Granfeldt Y, Björck I, Vessby B \& Asp N-G (1995) The influence of food structure on postprandial metabolism in patients with non-insulin-dependent diabetes mellitus. American Journal of Clinical Nutrition 61, 837-842.

Järvi A, Karlström B, Granfeldt Y, Björk I, Asp N-G \& Vessby B (1999) Improved glycemic control and lipid profile and normalized fibrinolytic activity on a low-glycemic index diet in type 2 diabetic patients. Diabetes Care 22, 10-18.

Jenkins DJA, Reynolds D, Leeds AR, Waller AL \& Cummings JH (1979) Hypocholesterolemic action of dietary fiber unrelated to fecal bulking effect. American Journal of Clinical Nutrition 32, 2430-2435.

Jenkins DJ, Wolever TM, Taylor R, Barker H, Fielden H, Baldwin JM, Bowling AC, Newman HC, Jenkins AL \& Goff DV (1981) Glycemic index of foods: a physiological basis for carbohydrate exchange. American Journal of Clinical Nutrition 34, 362-366.

Jenkins DJ, Wesson V, Wolever TM, Jenkins AL, Kalmusky J,
Guidici S, Csima A, Josse RG \& Wong GS (1988) Wholemeal versus wholegrain breads: proportion of whole or cracked grain and the glycaemic response. British Medical Journal 297, 958960.

Jenkins DJ, Wolever TM, Vuksan V, Brighenti F, Cunnane SC, Rao AV, Jenkins AL, Buckley G, Patten R, Singer W, Corey P \& Josse RG (1989) Nibbling versus gorging: metabolic advantages of increased meal frequency. New England Journal of Medicine 321, 929-934.

Jenkins D, Wolever T, Rao A, Hegele R, Mitchell S, Ransom T, Boctor D, Spadafora P, Jenkins A, Mehling C, Katzman-Relle L, Connelly P, Story J, Furumoto E, Corey P \& Würsch P (1993) Effect on blood lipids of very high intakes of fiber in diets low in saturated fat and cholesterol. New England Journal of Medicine 329, 21-26.

Jenkins D, Kendall C, Vuksan V, Augustin L, Mehling C, Parker T, Vidgen E, Lee B, Faulkner D, Seyler H, Josse R, Leiter L, Connelly P \& Fulgoni III V (1999) Effect of wheat bran on serum lipids: influence of particle size and wheat protein. Journal of the American College of Nutrition 18, 159-165.

Karlström B, Vessby B, Asp N, Boberg M, Gustafsson I, Lithell H \& Werner I (1984) Effects of an increased content of cereal fiber in the diet of type 2 (non-insulin-dependent) diabetic patients. Diabetologia 26, 272-277.

Landin K, Holm G, Tengborn L \& Smith U (1992) Guar gum improves insulin sensitivity, blood lipids, blood pressure, and fibrinolysis in healthy men. American Journal of Clinical Nutrition 56, 1061-1065.

Levi F, Pasche C, LaVecchia C, Lucchini F \& Franceschi S (1999) Food groups and colorectal cancer risk. British Journal of Cancer 79, 1283-1287.

Lichtenstein A (1998) Soy protein, isoflavones and cardiovascular disease risk. Journal of Nutrition 128, 1589-1592.

Liljeberg H, Granfeldt Y \& Björck I (1992) Metabolic responses to starch in bread containing intact kernels versus milled flour. European Journal of Clinical Nutrition 46, 561-575.

Liljeberg H, Granfeldt Y \& Björck I (1996) Products based on a high fiber barley genotype, but not on common barley or oats, lower postprandial glucose and insulin responses in healthy humans. Journal of Nutrition 126, 458-466.

Liu S, Willett W, Stampfer M et al. (1998) A prospective study of dietary glycemic load, carbohydrate and risk of coronary heart disease in US women. Federation of American Societies for Experimental Biology 12, A260.

Liu S, Stampfer M, Hu F, Giovannucci E, Rimm E, Manson J, Hennekens C \& Willett W (1999) Whole-grain consumption and risk of coronary heart disease: results from the Nurses' Health Study. American Journal of Clinical Nutrition 70, 412-419.

Ludwig D, Majzoub J, Al-Zahrani A, Dallal G, Blanco I \& Roberts S (1999) High glycemic index foods, overeating, and obesity. Pediatrics 103, E26.

Luscombe N, Noakes M \& Clifton P (1999) Diets high and low in glycemic index versus high monounsaturated fat diets: effects on glucose and lipid metabolism in NIDDM. European Journal of Clinical Nutrition 53, 473-478.

Manson JE, Hu FB, Rich-Edwards JW, Colditz GA, Stampfer MJ, Willett WC, Speizer FE \& Hennekens CH (1999) A prospective study of walking as compared with vigorous exercise in the prevention of coronary heart disease in women. New England Journal of Medicine 341, 650-658.

Powell JT, Franks PJ \& Poulter NR (1999) Does nibbling or grazing protect the peripheral arteries from atherosclerosis? Journal of Cardiovascular Risk 6, 19-22.

Rimm E, Aschemrio A, Giovannucci E, Spiegelman D, Stampfer M \& Willet W (1994) Vegetable, fruit, and cereal fiber intake and risk of coronary heart disease among men. Journal of the American Medical Association 275, 447-451. 
Ross SW, Brand JC, Thorburn AW \& Truswell AS (1987) Glycemic index of processed wheat products. American Journal of Clinical Nutrition 46, 631-635.

Salmeron J, Ascherio A, Rimm EB, Colditz GA, Spiegelman D, Stampfer MJ, Wing AL \& Willett WC (1997a) Dietary fiber, glycemic load, and risk of NIDDM in men. Diabetes Care 20, 545-550.

Salmeron J, Manson JE, Stampfer MJ, Colditz GA, Wing AL \& Willett WC (1997b) Dietary fiber, glycemic load, and risk of non-insulin-dependent diabetes mellitus in women. Journal of the American Medical Association 277, 472-477.

Stilling B, Mehlsen J, Hamberg O, Larsen JJ, Gram NC \& Madsbad S (1999) Effect of a new starch-free bread on metabolic control in NIDDM patients. Nutrition, Metabolism and Cardiovascular Diseases 9, 98-101.

Tagliaferro V, Cassader M, Bozzo C, Pisu E, Bruno A, Marena S, Cavallo-Perin P, Cravero L \& Pagano G (1985) Moderate guar-gum addition to usual diet improves peripheral sensitivity to insulin and lipaemic profile in NIDDM. Diabetes Metabolism 11, 380-385.

Torsdottir I, Alpsten M, Andersson H \& Einarsson S (1989) Dietary guar gum effects on postprandial blood glucose, insulin and hydroxyproline in humans. Journal of Nutrition 119, 19251931.

Trowell H (1978) Diabetes mellitus and dietary fiber of starchy foods. American Journal of Clinical Nutrition 31, S53-S57.

Virkamäki A, Ueki K \& Kahn C (1999) Protein-protein interaction in insulin signaling and the molecular mechanisms of insulin resistance. Journal of Clinical Investigation 103, 931943.

Wolk A, Manson J, Stampfer M, Colditz G, Hu F, Speizer F, Hennekens C \& Willett WC (1999) Long-term intake of dietary fiber and decreased risk of coronary heart disease among women. Journal of the American Medical Association 281, 1998-2004. 